\title{
Corynespora Leaf Spot of Papaya (Carica papaya L.) in Puerto Rico
}

\author{
Pedro Luis Meléndez and Julio Bird Piñero ${ }^{1}$
}

\section{INTRODUCTION}

The culture of papaya (Carica papaya L.) in Puerto Rico was limited mostly to home gardens until a few years ago. Recent introductions of choice papaya varieties has increased the demand considerably in Puerto Rican and New York markets for this tropical fruit. The municipalities of Aguadilla, Isabela, Camuy, Hatillo and Carolina are among those areas in which papayas are grown in Puerto Rico on a commercial scale.

A total of four million pounds of fresh papayas were harvested in 1965 and 1966, furnishing Island producers a gross income of $\$ 134, \$ 00$. Production, however, was extremely low in 1967 and 1969. Only $3 / 4$ million pounds of fresh fruits were harvested during the latter year (4). ${ }^{2}$ Spread of several fungal and viral diseases in all likelihood is directly, as well as indirectly, related to such production decline. Among the fungal diseases that occur most commonly (5), is a leaf spot caused by Pucciniopsis caricae Speg. and a fruit rot caused by Collectotrichum spp. "Bunchy top," believed to be caused by mycoplasma (12), and two mosaic diseases, also affect production of papaya in the Island $(3,1)$.

A new foliar disease of papaya, caused by the fungus Corynespora cassiicola (Berk. and Curt.) Wei, was reported in 1966 from St. Croix, Virgin Islands (2). This disease was considered to be a threat to the future successful cultivation of this crop in Puerto Rico due (1) to the close proximity of St. Croix and (2) to the frequent shipments of Solo papaya fruits to the San Juan markets. A survey was initiated to determine whether or not the fungus was already present in the papaya plantings of Puerto Rico. Studies on the biology of the fungus were conducted using an isolate originally obtained from infected papayas in St. Croix and isolates obtained during the survey. The present report includes the results of these investigations.

\section{REVIEW OF LITERA'TURE}

Corynespora cassiicola (Berk. \& Curt.) Wei, the causal agent of "greasy spot" or "papaya decline" in St. Croix, U. S. Virgin Islands (2), is a rela-

${ }^{1}$ Assistant Phytopathologist and I)irector, Department of Plant Pathology and Botany, Agricultural Experiment Station, Mayagiez Campus, University of Puerto Rieo, Río Piedras, P.R. Thanks are due to Mr. Arcángel Rodríguez for assistance during the rourse of these investigations.

2 Italic numbers in parentheses refer to Literature Cited, p. 425. 
tively new pathogen in the New World. It was reported for the first time in 1945 as Helminthosporium vignae Olive, Bain and Lefebvre and designated as a pathogen of cowpea (Vigna sinensis) and soybean (Glycine max) (7).

The fungus had been reported since 1945 on sesame (Sesamum indicum) and okra (Hibiscus esculentus) (11), on two species of cotton (Gossypium hirsutum and G. barbadense) (6) and on several other crops $(8,9)$.

The first report of the occurrence of the fungus on papaya (Carica papaya L.) was from the Philippines in 1923 (13). Leaves sent to the Commonwealth Institute Herbarium in England were affected by a fungus which $H$. Sydow described as Helminthosporium papayae. Stevens (10) in 1930 isolated a fungus in the Philippines that caused severe leaf spotting of papaya, which was similar to that described by Sydow. Symptoms of the disease were reproduced on healthy papaya plants inoculated with the pathogen under controlled conditions.

A seemingly new disease affecting several varieties of papaya in St. Croix was observed by Bird el al. (2) in 195ij. Diseased plants had watersoaked areas on the upper parts of their stems as well as on the petioles and leaves. The disease was given the common name "greasy spot" because affected areas often appeared greasy rather than wet. The fungus isolated from diseased trees was identified as $C$. cassiicola. Pathogenicity studies revealed the fungus to be highly pathogenic to papaya.

\section{MATERIALS AND METHODS}

\section{ISOLATING AND CULTURING THE FUNGUS}

Three isolates of Corynespora cassiicola were obtained from diseased papaya trees through single-spore isolations during the course of these studies. These were the "Santa Cruz" isolate obtained from diseased Solo papaya leaves from St. Croix; the Gurabo isolate obtained from diseased stems and petioles of papaya hybrids in the Gurabo Substation; and the Isabela isolate obtained from diseased Puerto Rican papaya trees in the Isabela Substation.

Diseased plant material (leaves, petioles, and stems) to be used for single-spore isolation was washed with tap water, surface-disinfected with clorox (10 percent solution) for 5 minutes, rinsed with distilled water and placed in a moist chamber. Twenty-four hours after the plant material was placed in the moist chamber, conidia could be observed on some of the older lesions with the aid of the dissecting microscope. Conidia were picked up with a sharp needle and placed in the middle of Petri plates containing potato-dextrose agar (PDA). Cultures were incubated at $28^{\circ} \mathrm{C}$. and transferred montly to fresh PDA.

$\mathrm{V}-\mathrm{S}$ juice agar ( $\mathrm{V}-\mathrm{SA}$ ) was used to induce sporulation of the fungus. The medium was prepared by mixing $200 \mathrm{cc}$. of $\mathrm{V}-8$ juice with $800 \mathrm{cc}$. distilled 
water and $20 \mathrm{~g}$. of Bacto Agar. This resulted in the production of abundant conidia and mycelium for inoculation purposes.

\section{PATHOGENICITY STUDIES}

\section{Inoculation of Solo Papaya Plants}

A total of 48 two-month-old Solo papaya plants were inoculated with single-spore cultures of the St. Croix, the Gurabo, and the Isabela isolates of $C$. cassiicola. The inoculum was prepared by blending a 12-day-old culture of each isolate in a Waring Blendor for 5 seconds at the rate of one Petri dish culture per $100 \mathrm{cc}$. of distilled water, plus one drop of detergent (Triton). Plants were inoculated by wetting the leaves, petioles and stems with a camel's hair brush containing inoculum. Control plants were treated with a suspension of sterile PDA. Inoculated plants were covered with white polyethylene bags and placed on a bench in the greenhouse $\left(84^{\circ} \mathrm{F} . \pm\right.$ 5). Twenty-four hours after inoculation, the bags were removed and the plants left on the bench for the duration of the experiment.

\section{Inoculation of Puerto Rican Papaya Plants}

The aforementioned techniques also were used to inoculate local papaya plants; however, single-spore cultures of the three isolates were established on V-SA, and the cultures were only 10 days old when used as inoculum.

\section{GIROWTH STUDIES}

\section{Effect of $p H$}

Only the Gurabo isolate was studied in this experiment. Eight-day-old cultures of the fungus grown on PDA were cut into $8 \mathrm{~mm}$. discs containing only hyphal tips. Each $15 \mathrm{cc}$. PDA dish was seeded with one of the dises and incubated at $28^{\circ} \mathrm{C}$. The particular PDA medium had been adjusted previously to the desired $\mathrm{pH}$ with either lactic acid at 25 percent or normal $\mathrm{NaOH} . \mathrm{pH}$ values of from 3 to 12 were tested and a total of 12 plates were included in each treatment. Radial growth measurements were taken 6 days after incubation.

\section{Effect of Temperature}

All three isolates of $C$. cassiicola were tested to determine temperature requirements as well as the optimum, maximum and minimum temperatures for growth. Five mm. discs were cut from fresh cultures of each isolate and introduced into Petri dishes, each romtaining $15 \%$ PI)A. Seeded plates were incubated at $S^{\circ}, 12^{\circ}, 16^{\circ}, 20^{\circ}, 24^{\circ}, 24^{\circ}, 32^{\circ}, 36^{\circ}$, and $40^{\circ} \mathrm{C}$. for 6 days, after which colonies were measured. 


\section{Effect of Various Culture Media on Growth and Sporulation}

The following culture media were tested for growth and sporulation: cornmeal agar (CMA), oatmeal agar (OMA), bean pod agar (BPA), V-S juice agar (V-SA), nutrient agar (NA), papaya agar (PA), and potatodextrose agar (PDA).

PA was prepared by macerating $200 \mathrm{~g}$. of papaya fruit in a Waring Blendor for 2 minutes. The resulting juice was passed through cheesecloth and mixed with $20 \mathrm{~g}$. agar. Distilled water was added to complete $1,000 \mathrm{ml}$.

The Gurabo isolate was used throughout this experiment. Eight-mm., PDA discs containing hyphal tips of the fungus were cut with a cork borer. Fresh plates of each media were seeded each with a disc and incubated at $28^{\circ} \mathrm{C}$. for 6 days, after which the diameter of each fungal colony was recorded.

Visual examination of the density of each colony also was recorded. The following rating was established to evaluate the fungal growth within each medium studied:

\begin{tabular}{cl} 
Rating & \multicolumn{1}{c}{ Description of the colony } \\
1 & Colony nearly transparent, no aerial growth \\
2 & Colony very thin, mycelium sparse, no aerial growth \\
3 & Colony thin, no aerial growth \\
4 & Mycelium thick, some aerial growth \\
5 & Mycelial mat thick or very dense, abundant aerial mycelium
\end{tabular}

The following formula was used to estimate the total growth of the fungus on each medium: $\pi r^{2} h$, where $\pi=3.14, r=$ the radius of the colony, and $h=$ height or thickness of the colony according to the rating given by visual examination.

Conidial production on each medium was determined from cultures 7 , 9 , and 11 day's old. A plate (cont aining medium and fungus) was emptied into a Waring Blendor, diluted with 50 cc. distilled water and macerated for five seconds. A drop of the suspension was placed in a blood haemacytometer (Hausser $\mathrm{Hy}$-Lite Plate) and the conidia counted under low magnification of the compound microscope. The average number of conidia present in $1 \mathrm{sq}$. mm. of the haemacytometer was multiplied by 10,000 and the total number of conidia per ce. calculated.

\section{CONIDIA AND CONIDIOPHORE MEASUREMENTS}

The description of the Gurabo and Isabela isolates is based on the measurements at random of 100 conidia and 50 conidiophores each of both isolates. Diseased leaves were collected in the field, washed with tap water, rinsed with distilled water, and platced in a moist chamber for 48 hours after which time large numbers of conidlia and conidiophores were observed. 
Measurements were made under low magnification of the compound microscope.

\section{EXPERIMENTAL RESULTS}

OCCURRENCE OF C. cassiicola IN PUERTO RICO

A number of papaya fields throughout the Island were checked for presence of the fungus during 1966. Plantings established in the Gurabo and Isabela Substations, as well as in the Solis field in the Main Station, were affected by the disease. In the Isabela Substation, trees of both Solo and Puerto Rican varieties were affected equally. Diseased plants showed severe spotting, often involving the whole leaf area as well as the petioles

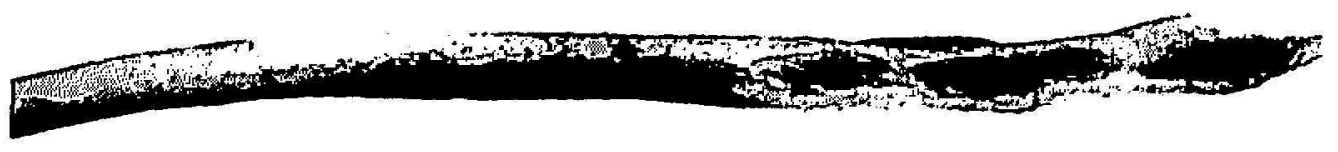

\section{A}

Fig. 1, A.-Lenticular spots induced by Corynespora cassiicola on a petiole of a Solo papaya plant.

and stems. Young spots were small, yellowish brown and water-soaked. On the leaves they appeared very clearly as minute, transparent areas when viewed against the light. Old spots were circular to irregular, generally brown with whitish centers and surrounded by a yellow border. These spots were 2 to $10 \mathrm{~mm}$. in diameter and appeared on both leaf surfaces. Spots on the petioles and stems were lenticular in shape (figs. 1, A, 1, B and $1, \mathrm{C})$. Length varied from 3 to $5 \mathrm{~mm}$. but width was generally constant (2 mm.).

Single-spore cultures of the fungus were obtained repentedly from spotted leaves and petioles of both Solo and Puerto Rican papayas when kept in moist chambers. Colonies established on PDA were cottony and gray and changed the color of the medium to dark brown or jet black after 10 to 12 days. These characteristics were similar to those described by Bird et al. (2) for the "greasy spot" fungus isolated from diseased papaya in St. Croix. 


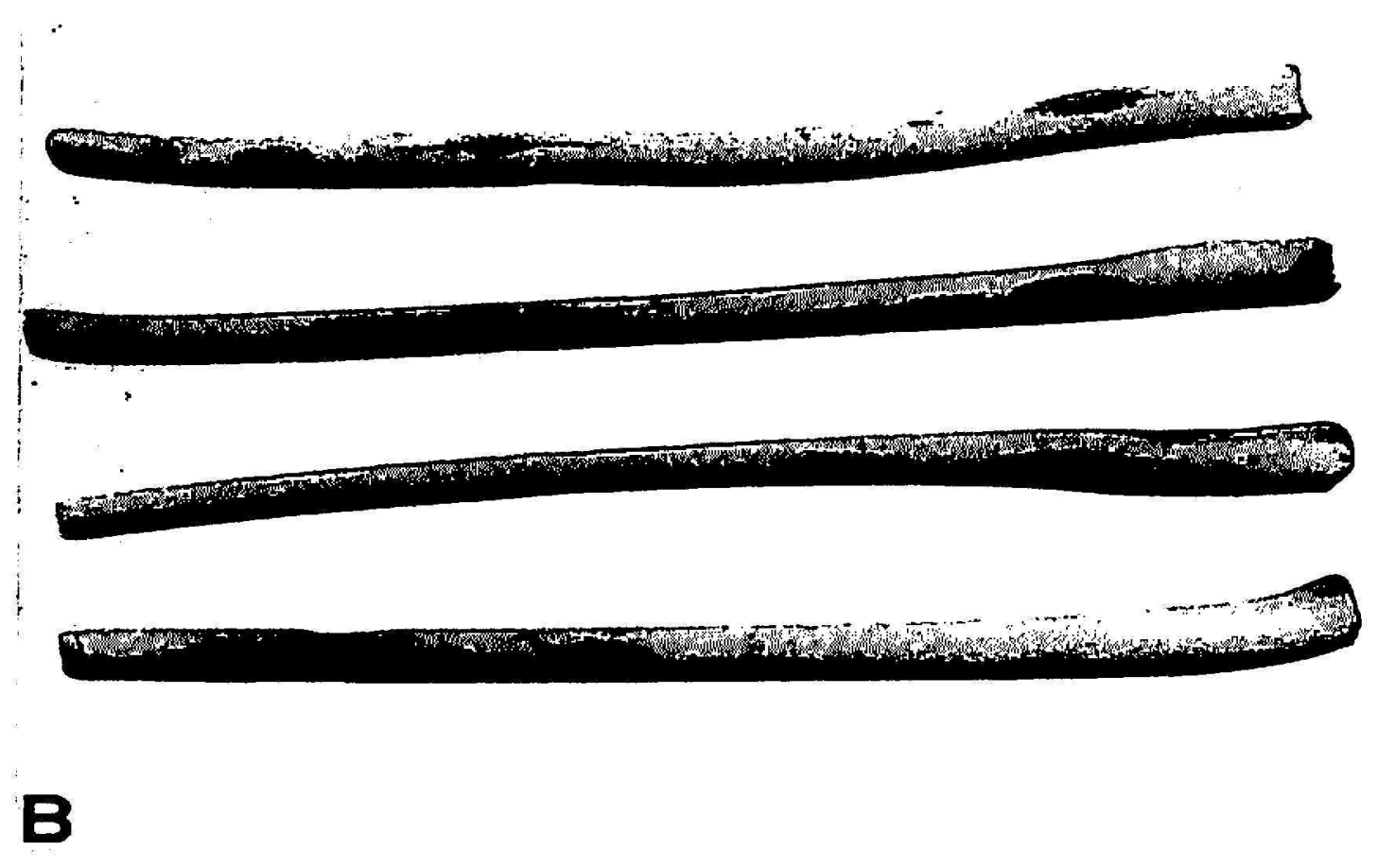

FIG. 1, B.-Ienticular spots induced by Corynespora cassiicola on petioles of Puerto Rican papaya plants.
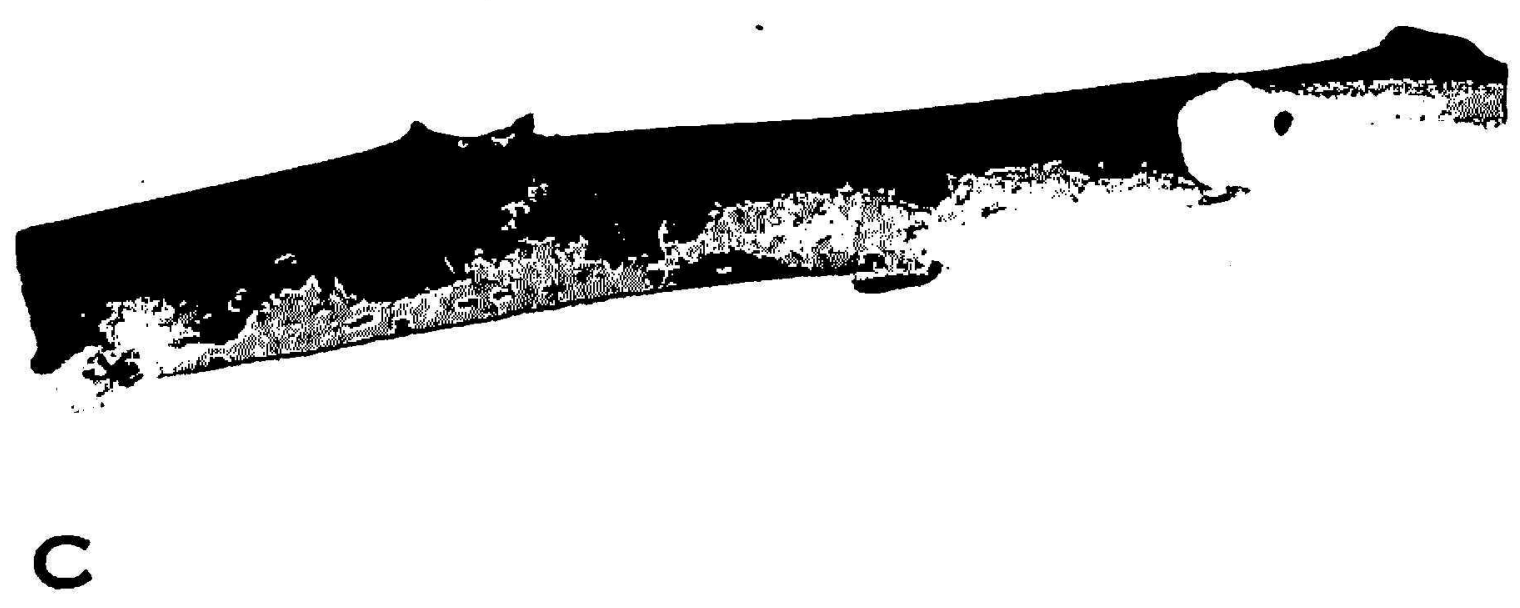

FIG. 1, C.--Lenticular spots induced by Corynespora cassiicola on a stem of a Puerto Rican papaya plant. 
The morphology of the fungus was studied on diseased leaves collected from Gurabo and Isabela and compared with the morphology of the fungus from diseased leaves obtained from St. Croix. No significant morphological differences existed between the three isolates. In general, conidiophores were dark brown, single, erect to slightly curved, unbranched, with a swollen basal cell, had 4 to 12 septations, and measured 102 to $374 \mu \mathrm{X}$ 5.1 to $11.9 \mu$ in diameter. Conidia were borne singly, occasionally catenulate, connected by a hyaline isthmus to the conidiophore or to the conidium below. They were light brown to almost hyaline, cylindric to obclavatecylindric, straight to slightly curved, 2 to 16 transverse pseudoseptations,

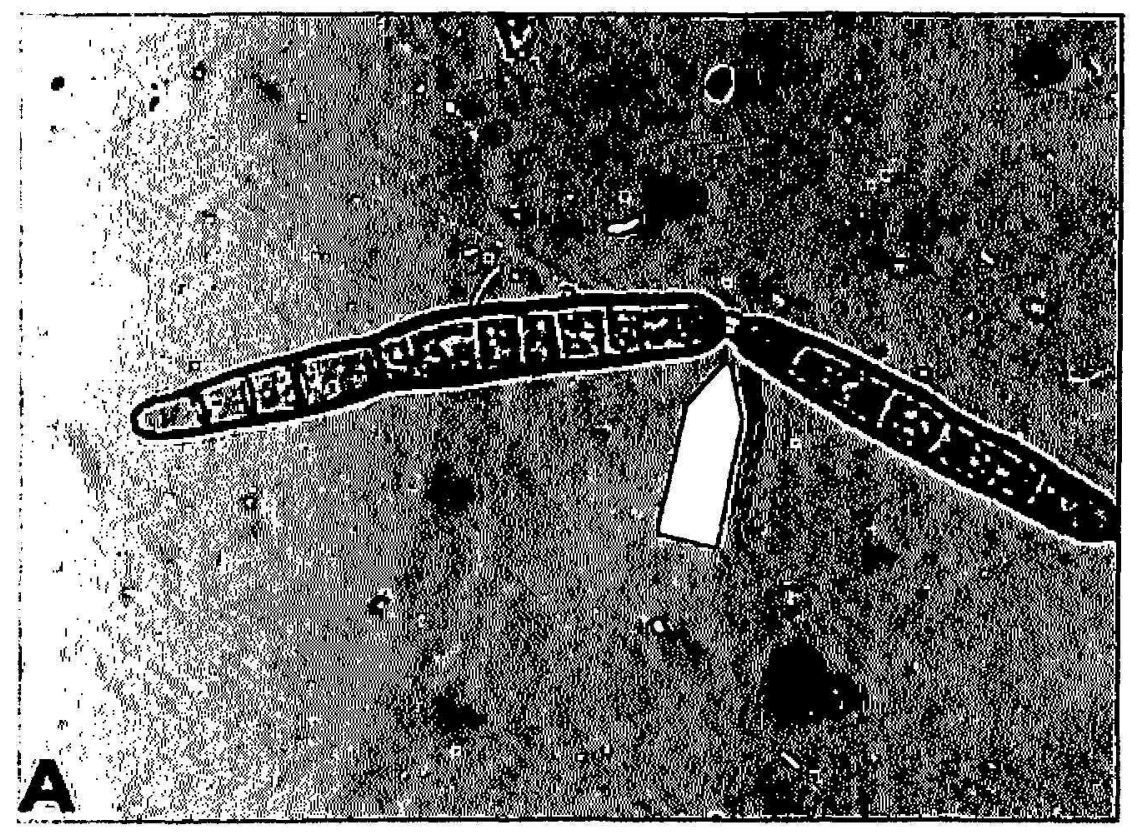

Fıg. 2, A.-Conidia of Corynespora cassiicola connected by a hyaline isthmus (arrow).

with bipolar germination and measured 51 to $306 \mu \times 8.7$ to $13.6 \mu$ in diameter (figs. 2, A, 2, B, and 2, C).

\section{PATHOGENICITY EXPERIMENTS}

\section{Inoculation of Solo Papaya Plants}

Twenty-four hours after inoculation, minute, water-soaked areas occurred on both leaf surfaces of plants inoculated with the three isolates. Three days after inoculation, leaf spots were large and the petioles as well as stems of inoculated plants showed water-soaked lesions which were lenticular in shape (fig. 3). The foliage of diseased plants turned yellow and began to abscise.

Ten days after inoculation, the diseased plants had lost most of their leaves except for 2 or 3 young apical ones. These apical leaves gave an 
umbrella-like appearance to the test plants (2). Control plants remained healthy throughout the duration of the experiment. The fungus was recovered from all the inoculated plants.

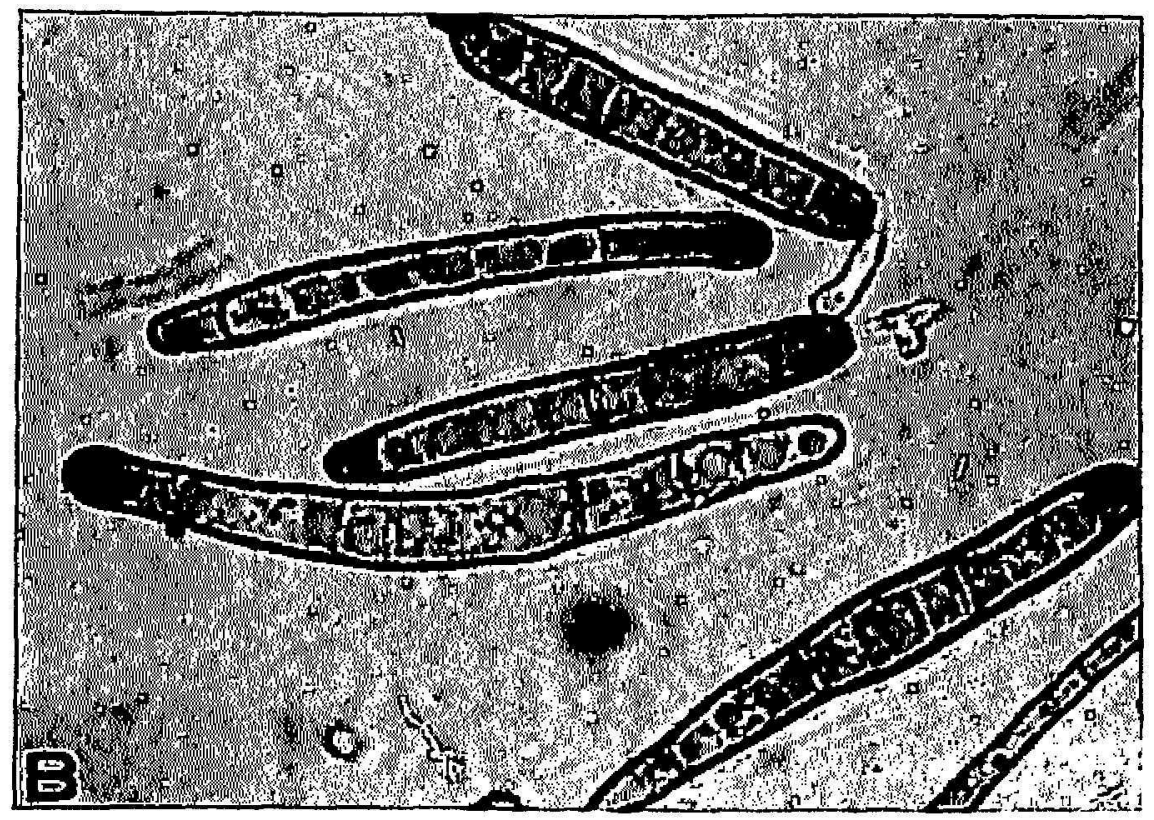

Fig. 2, B.-Conidia of ('ory iespora cassiicoia ubtained un potato-dextrose agar.

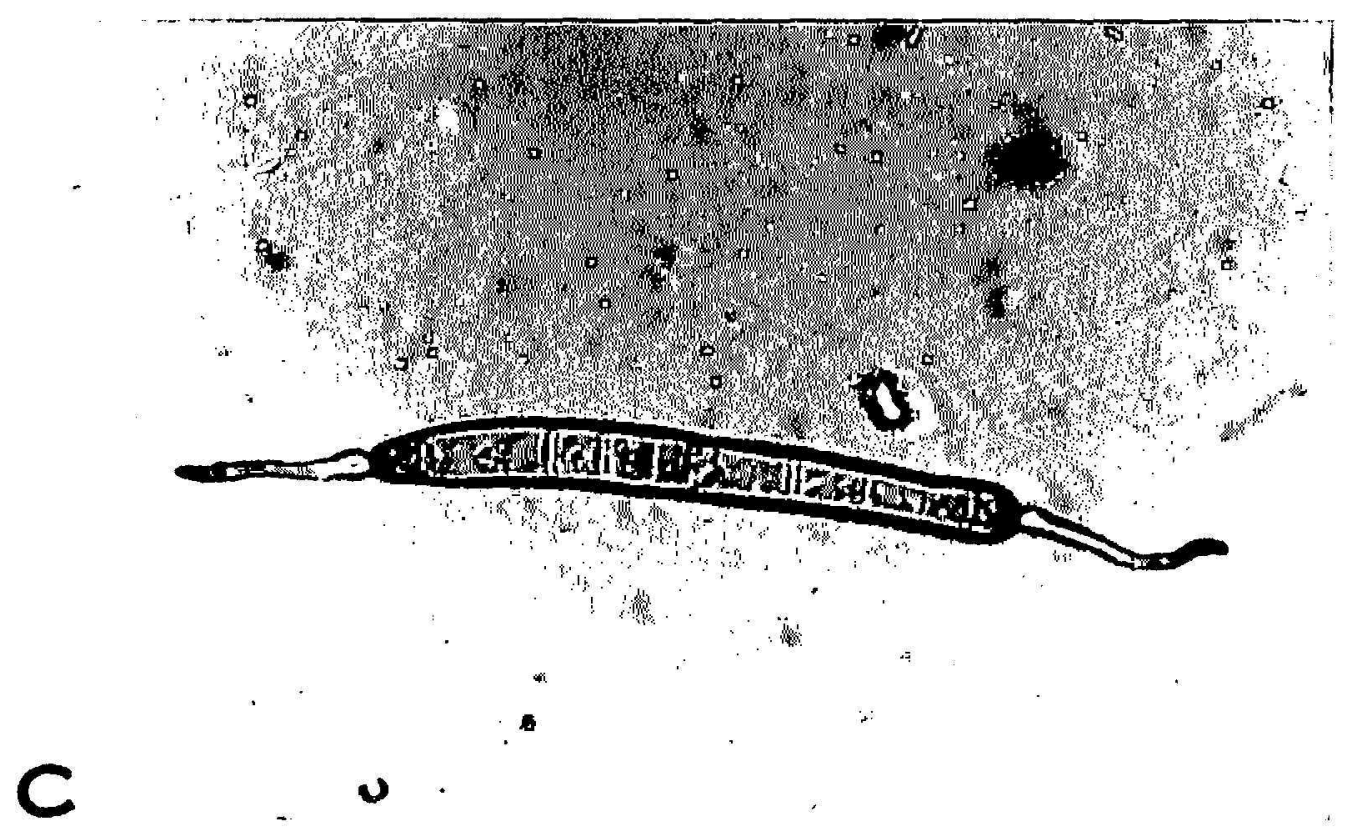

Fra. 2, C.-Bipolar germination of Corynespora cassicicola.

Symptoms induced on the plants by the three isolates were similar. All three invaded the leaves, petioles and stems and proved equally pathogenic to this papayal variety. 


\section{Inoculation of Puerto Rican Papaya Plants}

Symptoms of these plants were observed as early as those on Solo papaya inoculated with the fungus and at first followed the same pattern. However, 3 days after inoculation, spots on the leaves were of various sizes (2 to 15 $\mathrm{mm}$. in diameter) and irregular in shape. The leaves of some of the inoculated plants appeared scorched and had large coalescing, light brown lesions. The petioles and stems had lesions that were 3 to $6 \mathrm{~mm}$. long, circular to lenticular in shape, but more numerous than those observed on Solo papayas (fig. 1, B). One week after inoculation, 90 percent of the inoculated

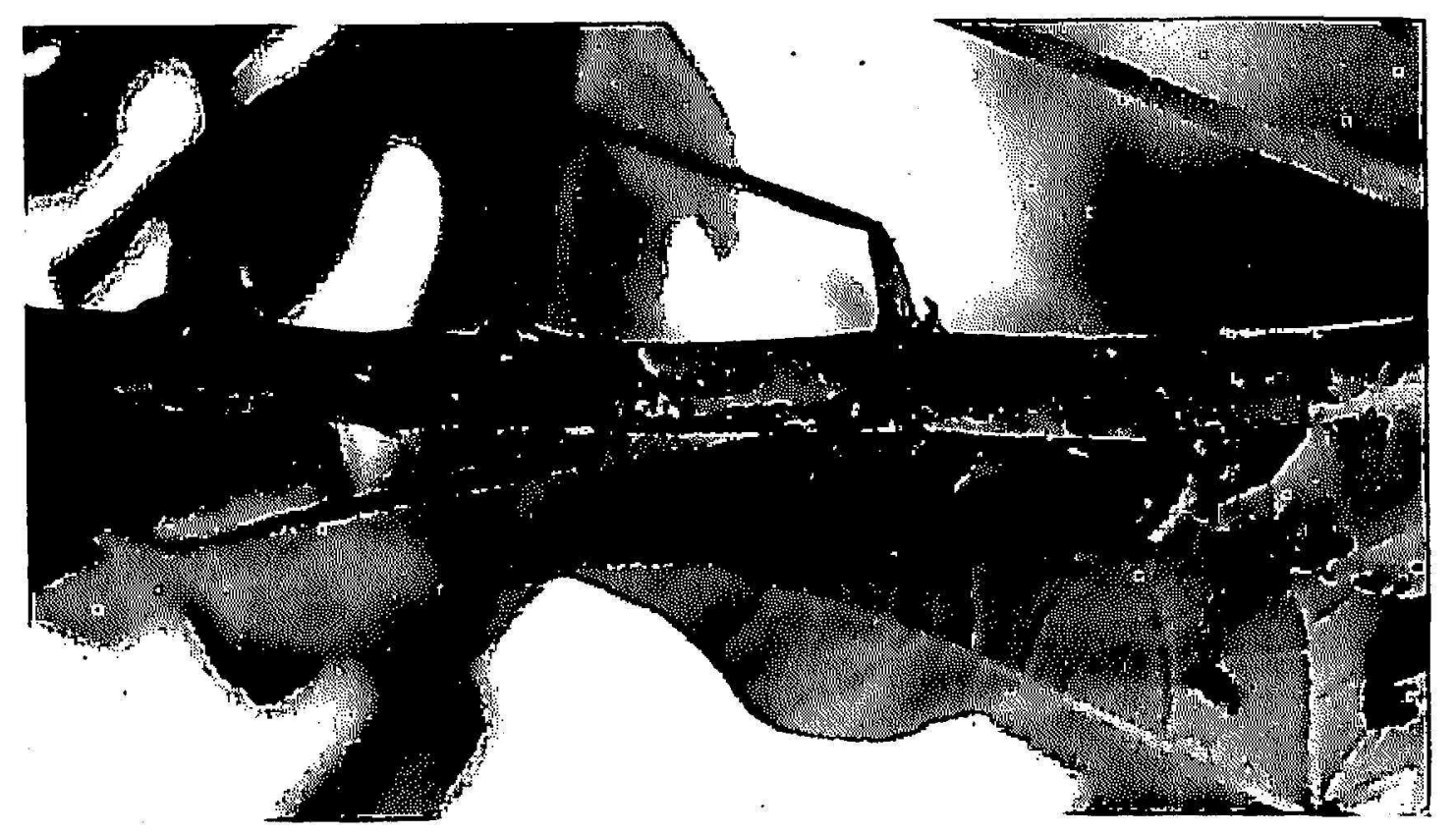

Fig. 3.-Symptoms induced by Corynespora cassicola on the stem of a Siolo papaya plant 3 days after inoculation.

plants were defoliated. Those leaves which remained on the trees showed spots which were gray in color and very irregular. All three isolates of the fungus behaved more or less similarly, except that symptoms induced by the Santa Cruz isolate appeared later than those induced by the other two isolates.

\section{(;ROWTH S'TUDIKS}

EFFECT OF PH

The fungus was favored by low hydrogen-ion concentrations, although it grew well on a wide range of $\mathrm{pH}$ values. The optimum initial $\mathrm{pH}$ for radial growth lies between 7.0 and 8.0 (fig. 4); however, it grew well on media adjusted to $\mathrm{pH}$ values of from 5.0 to 9.0. Radial growth was very 
poor at $\mathrm{pH}$ values of 3.0,4.0,10.0, and 11.0. Growth did not occur at a $\mathrm{pH}$ of 12 (fig. 4).

\section{EFFECT OF TEMPERATURE}

Radial growth increased with increases in temperature up to $28^{\circ} \mathrm{C}$., which was optimum for all three isolates (figs. $\overline{5}$ and 6 ). There was a drastic drop in radial growth of all isolates when grown at temperatures above

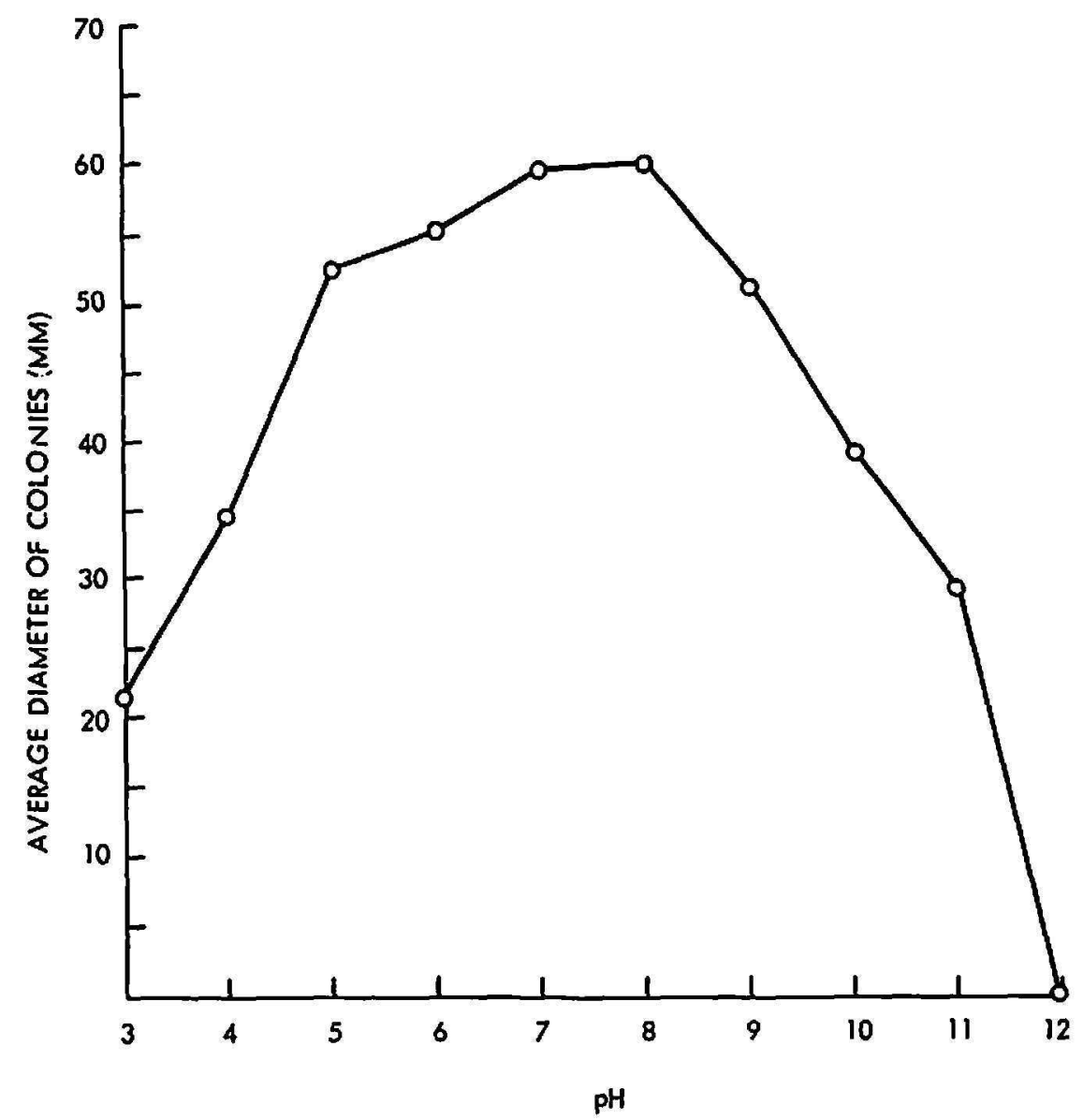

FIg. 4.-A verage size of colonies of ('orynespora cassiicola after 6 days' incubation on PDA at different $\mathrm{pH}$ values.

$32^{\circ} \mathrm{C}$. The maximum temperature at which growth occurred was $36^{\circ} \mathrm{C}$., the minimum $12^{\circ} \mathrm{C}$. None of the isolates grew at $8^{\circ}$ and $40^{\circ} \mathrm{C}$. (figs. i) and 6$)$.

\section{EFFECT OF THE CULTCRE MEUIA}

PA and V-8A were the best media for radial growth of the fungus. They were followed by BPA, NA, IDA, OMA and CMA. Based on visual examination of the density of the fungal colonies on eatch medium tested, the following ratings were given: $V-S \Lambda$ and $P \Lambda=5, B P A$ and $P D A=4$, OMA $=2$, and NA $=1$. Colonies on V-SA and PA were dense and raised. 


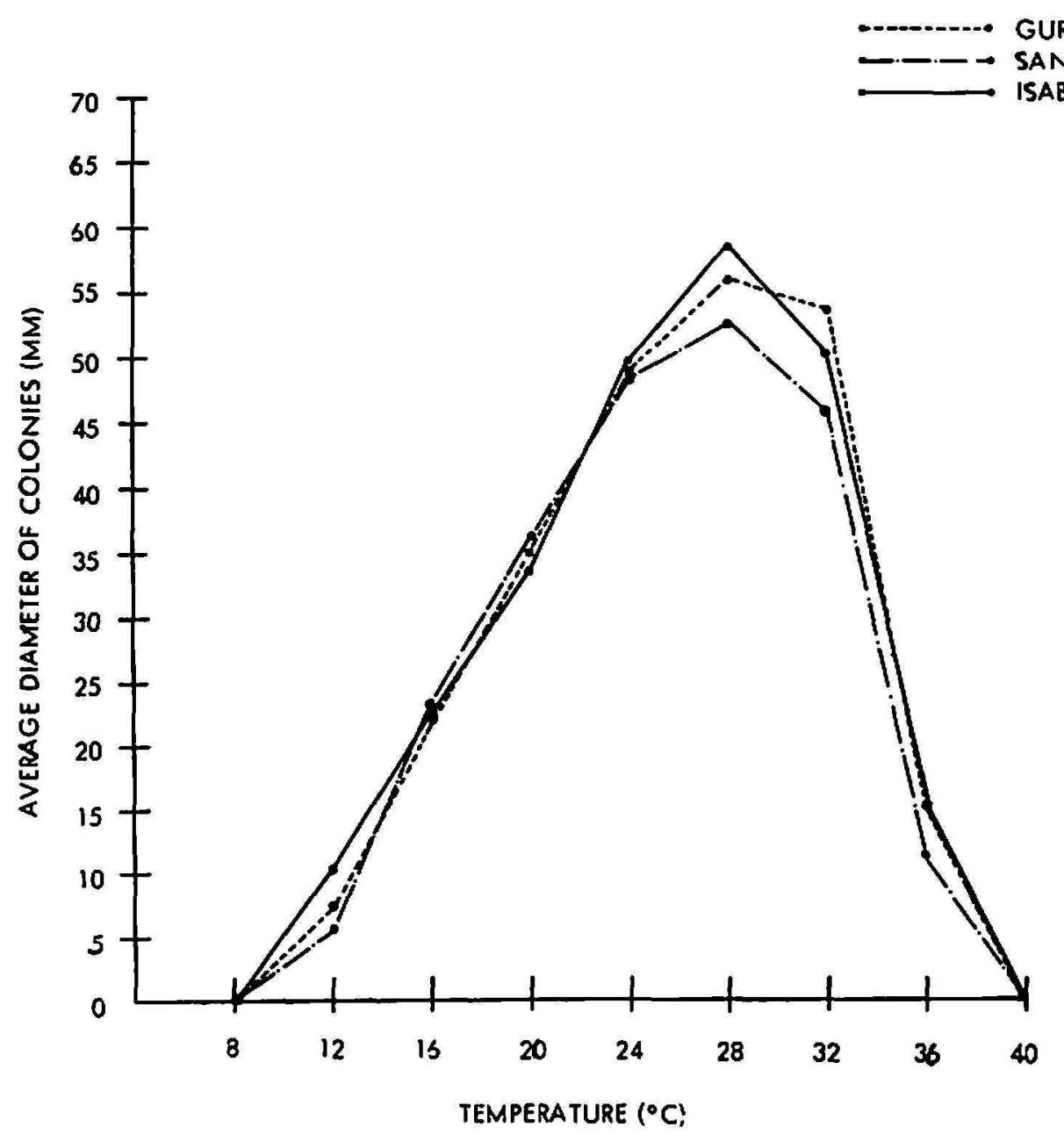

Fig. 5. - Size of colonies of three isolates of Corynespora cassiicola after (i days' incubation on potato-dextrose agar at different temperatures.

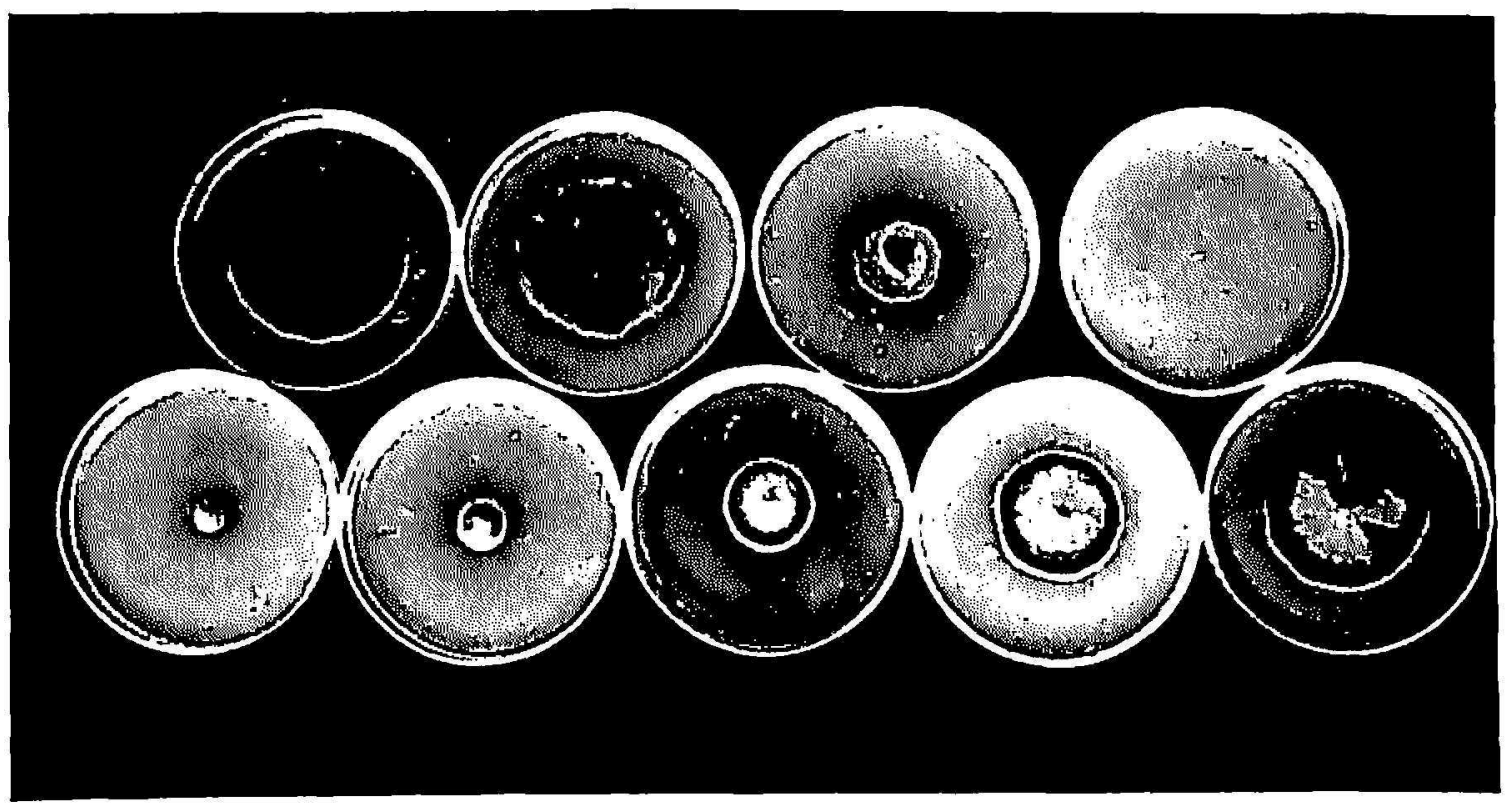

Fı. (i.--Radial sprend of Corynespora cassiicola after $(i$ days incubation at different temperatures. Upper row (, to $\mathrm{R}$ ) $28^{\circ}, 32^{\circ}, 36^{\circ}$, and $40^{\circ} \mathrm{C}$; lower row (L to R) $8^{\circ}, 12^{\circ}, 16^{\circ}, 20^{\circ}$, and $24^{\circ} \mathrm{C}$. 
By using the formula given previously, growth on both these culture media was approximately 6 times that on NA, the poorest medium. The charateristics of the fungal colonies on each culture medium were as follows:

1. CMA-Colony gray to white, growth appressed and sparse. Fungus changed the medium to olive green around the colony and to brown under the colony.

2. OMA-Colony white with brown to dark ramifications, very thin, mycelium sparse, the medium around the colony remained white, but changed to brown under the colony.

3. NA-Colony white, oily, transparent, no aerial growth, medium remained unchanged.

4. BPA-Colony yellowish brown, medium under the colony was changed to dark brown or black while that around the colony remained unchanged; some aerial growth was present and the mycelium was thick.

5. PIA-Colony gray (chinchilla), sometimes forming white sectors, mycelium thick, aerial mycelium occasionally present. Medium changed to dark brown or to jet black in old cultures.

6. PA-Colony whitish with raised center, floceose (cottony or wooly), tuft and dense.

7. V-SA-Colony whitish with raised center, floccose or wooly, dense, tuft.

All colonies, except those on OMA, had smooth or regular margins.

The effect of each medium on sporulation by the fungus is shown in fig. 7 . The best media for growth of the fungus were also best for sporulation. Sporulation on NA was very poor, and sporulation did not occur on CMA.

\section{DIsCussiox}

The fungus has been found in relatively few of the papaya plantings of the Island. This possibly is an indication that the pathogen is relatively new to Puerto Rico. The Puerto Rican papaya obviously is as susceptible to the fungus as the Solo papaya of St. Croix; naturally infected trees in the field, as well as artificially inoculated ones, develop severe symptoms of the disease.

The fungus doubtlessly soon will be spread throughout the Island. It thus will be advantageous to growers to initiate spray programs to protect their crops of papaya from invasion by this pathogen. In Florida (8), fungicides such ats Maneb or Zineb, applied every 7 to 10 days at the rate of $2 \mathrm{lb} . / 100$ gal. of water, have proved effective in controlling this fungus on hydrangea and azalea. In St. Croix (2), Maneb applied every 7 to 10 days at the rate of $1 \frac{1}{4} \mathrm{Jb} . / 50$ gal. of water, gives satisfactory control of the disease on papaya.

Evidence presented in this paper indicates that the three isolates of $C$. 
cassiicola (Santa Cruz, Gurabo, and Isabela) studied are identical. Spencer (9) studied 14 isolates of the fungus from four different hosts and found at least two distinguishable races, based on symptoms expressed by two plant species of 24 tested. In our studies, the three isolates were similar in growth habits in culture media, in response to varying temperature, in

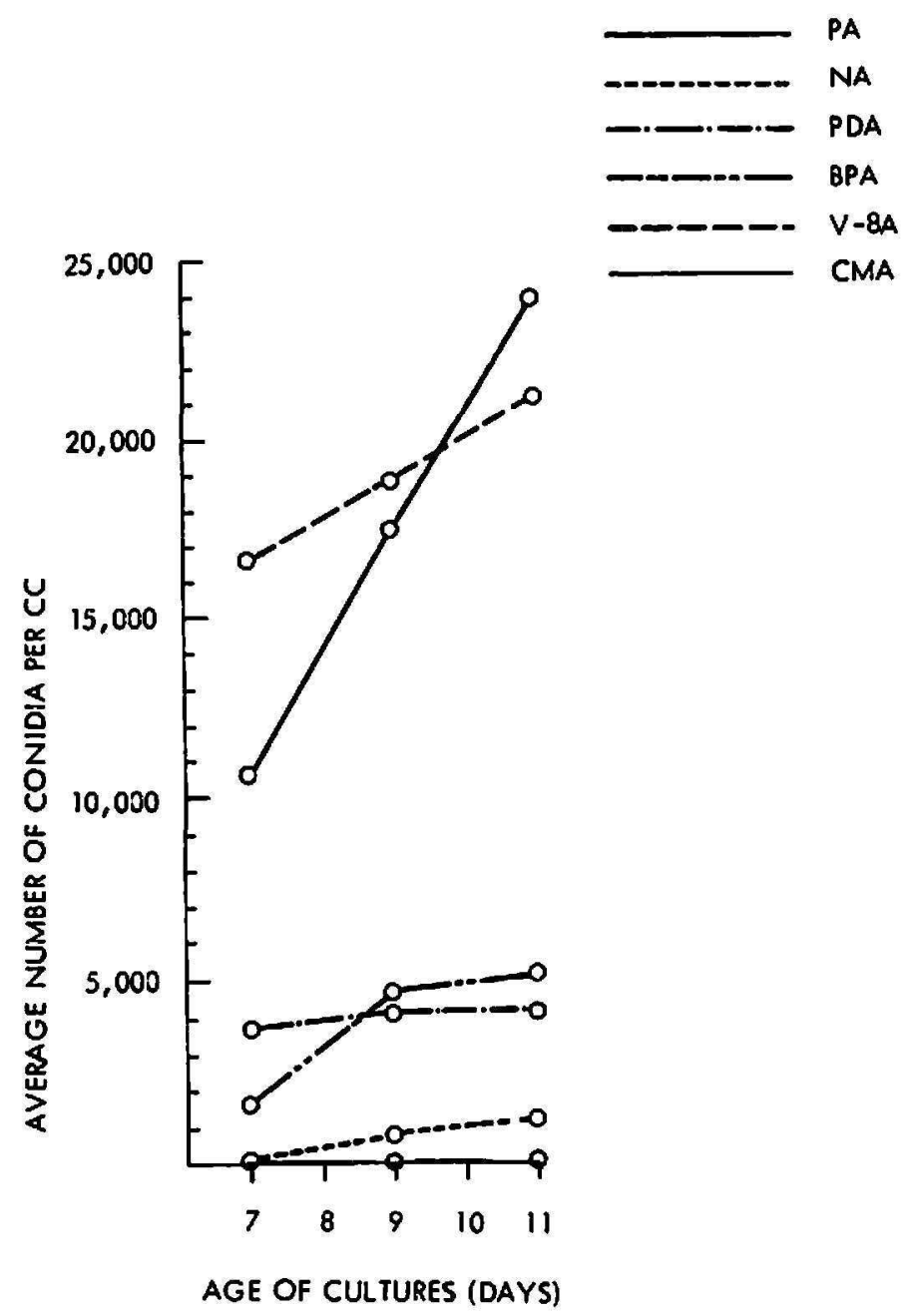

Fici, 7.- Effect of different culture media and age of culture on production of conidia by Corynespora cassiicola. The media employed were papaya agar (PA), V-8 juice agar (V-8A), bean-pod agar (BPA), potato-dextrose agar (PI), uutrient agar (NA), and cormmeal agar (CMA).

symptoms expressed by the hosts, and in morphology. In morphology, they compared to Wei's (1.4) description of the fungus except that conidia on the spots of diseased plants were much longer. All three isolates were highly virulent on the Solo as well as on the Puerto Rican valriety of papaya. However, when plants of both varieties were inoculated with cultures which were maintained in the laboratory for a month or more, the fungus failed to infect the plants. This strongly suggests that the fungus loses its virulence when kept for prolonged periods in the laboratory. This phenomenon also 
was observed by Olive et al. (7) and Bird et al. (2). Therefore, if pathogenicity trials conducted with the fungus are to succeed, the inoculum should be obtained from either fresh cultures established from fresh conidia produced on lesions in the field or from diseased plants kept in the greenhouse.

\section{SUMMARY}

The fungus Corynespora cassiicola (Berk. \& Curt.) Wei, causal agent of "greasy spot" or "papaya decline" in St. Croix, was found invading papaya plants of both Solo and Puerto Rican varieties in the Gurabo and Isabela Substations and in the Solis field in the Main Station. Plants of both varieties in the field appeared severely affected by the fungus as evidenced by heavy spotting on the foliage and the stems and by premature defoliation of the trees. Pathogenicity tests conducted with three isolates of the fungus isolated from Gurabo (Gurabo isolate), from Isabela (Isabela isolate), and from diseased-papaya plants from St. Croix (Santa Cruz isolate), proved that it is highly pathogenic to both Solo and Puerto Rican papayas. Optimum temperature and optimum $\mathrm{pH}$ for growth of the fungus, as well as the best medium for growth and sporulation, were determined. Cultural characteristics, response to varying temperatures, morphology, and symptoms expressed by inoculated plants of both papaya varieties were similar for all three isolates studied.

\section{RESUMEN}

Se determinó que el hongo Corynespora cassiicola (Berk. \& Curt.) Wei, que causa el tizón de la papaya en la isla de Santa Cruz, también causa la misma enfermedad en Puerto Rico. El organismo se aisló de plantas afectadas de las variedades Solo y Puerto Rico procedentes de predios experimentales y comerciales. La enfermedad ataca la papaya severamente en los llanos costeros húmedos $\mathrm{y}$ en las áreas montañosas de la costa norte de la Isla. Se caracteriza por la presencia de numerosas manchas foliares y lesiones lenticulares en los tallos y pecíolos. Las lesiones varían en tamaño, dependiendo en buen grado de la humedad prevaleciente. Bajo condiciones óptimas para su desarrollo, esta enfermedad de la papaya puede causar la total defoliación de los árboles afectados.

En pruebas llevados a cabo bajo condiciones contraladas se confirmó que el organismo causante es muy virulento, particularmente en las variedades Solo y Puerto Rico. También se determinaron las condiciones óptimas para su crecimiento y esporulación. Todos los subcultivos estudiados mostraron ser idénticos morfológicamente $y$ su comportamiento fue similar a temperaturas vatrias y diversos valores $\mathrm{pH}$. Igualmente demonstraron poseer 
el mismo grado de virulencia respecto a las variedades de papaya mencionadas.

\section{LITERATURE CITED}

1. Adsuar, J., Studies on the virus diseases of papaya (Carica papaya L.) in Puerto Rico. I. Transmission of papayn mosaic, Agr. Exp. Sta. Univ. P.IR. Tech. Paper $1,1946$.

2. Bird, J., Krochmal, A., Zentmyer, G., and Adsuar, J., Fungus diseases of papaya in the U.S. Virgin Islands, J. Agr. Univ. P.R. 50 (3) : 186-200, 1966.

3. Cook, M. T., New virus diseases of plants in Puerto Rico, P.R. Dept. Agr.J. 15: $193-5,1931$.

4. Departamento de Agricultura, Oficina de Estadísticas Agrícolas, Boletín Mensual de Esladisticas Agricolas, IX (6), 1969.

5. Index of plant disenses in the United States, US1)A. Agricultural Handbook No. $165,1960$.

6. Jones, J. P., A leaf spot of cotton caused by Corynespora cassiicola, Phytopathology $51: 305-8,1961$.

7. Olive, L. S., Bain, D. C., and Lefebvre, C. L., A leaf spot of cowpen and soybean eaused by an undescribed species of Helminthosporium, Phytopatholog!! 35 : 822$31,1945$.

8. Sobers, E. K., A leaf spot discase of azalea and hydrangea caused by Corynespora cassiicola, Phytopathology 56: 455-7, 1966.

9. Spencer, J. A., and Walters, H. J., Study of variations in Corynespora cassiicola, Phylopathology 52: 28 (Abstr.), 1962.

10. Stevens, F. I. and Celino, M. S., Papaya leaf spot, Philippine Agr. 21 (1): 9-14, 1932.

11. Stone, W. J. and Jones, J. P., Corynespora blight of sesame, Phytopathology 50: 203-6, 1960.

12. Story, G. E. and Haliwell, R. S., Association of mycoplasma-like organism with the bunchy top disease of papaya (Carica papaya) in the Dominican Republic, Phytopathology 69: 118 (Abstr.), 1969.

13. Sydow, H., Ann. Mycol., Berl., 21, 1 and 2, p. 105, 1923.

14. Wei, C. T., Notes on Corynespora, Commonwealth Mycol. Inst., Mycological Paper No. 34, Kew, Surrey, England, Aug. 1950. 